ORIGINAL SCIENTIFIC PAPER

\title{
INVESTIGATING THE MEDIATOR ROLE OF LOGISTIC SERVICE QUALITY IN RELATION BETWEEN RELATIONSHIP FLEXIBILITY AND RELATIONSHIP SATISFACTION
}

\author{
ERCAN Esra ${ }^{1}$, ÇELIK Mazlum \\ ${ }^{1}$ Hasan Kalyoncu University, Faculty of Economics, Administrative and Social Sciences, Department of Business Administration \\ E-mails:ercan.esraercan@hotmail.com; mazlum.celik@hku.edu.tr
}

\begin{abstract}
The aim of study is to investigate the mediator role of logistic service quality in relation between relationship flexibility and relationship. In order to get data, a questionnaire form was sent to 1627 business managers registered in Gaziantep Chamber of Industry and 366 of them returned. According to the results of the analysis made with the data collected, it was found that the relationship flexibility positively affects the logistics service quality and the logistic service quality to the relationship satisfaction. However, it was observed that the the relationship flexibility did not affect the relationship satisfaction significantly. In addition, Sobel test was applied to determine the mediation effect and the mediation role of logistics service quality was determined in the effect of relationship flexibility on relationship satisfaction.
\end{abstract}

Keywords: Relationship Satisfaction, Logistics Service Quality, Relationship Flexibility

JEL:L80

DOI: 10.5937/intrev2103071E

UDC: 005.336.3:658.724

005.42

COBISS.SR-ID 55093257 


\section{INTRODUCTION}

In markets where there is less stability, the demand is very volatile, which makes it difficult for companies in terms of capacity, order and resource planning against these variable demands [44]. One of the main purposes of these plans is to increase the profitability of the company through customer satisfaction. So relationship satisfaction is an important variable for all companies[1]. Relationship satisfaction does not only occur as a result of a selling but refers to a general emotional state that develops between the customer and the company[14] Relationship satisfaction is affected by many factors, from the trust, perceived value to communication [9] According to Yu et al.[46], relationship satisfaction is affected by relationship flexibility and logistics service quality.

In this study, in order to examine the relationship between relationship flexibility and relationship satisfaction, a structural equation model was created. At the same time, it was investigated whether logistics service quality has a mediating role on this relation. It is believed that the need for flexibility created by the uncertainty that becomes important and intensified day by day will contribute to the literature due to the determination of the effect of the service quality and the level of satisfaction with the business relations developed between enterprises.

\section{CONCEPTUAL FRAMEWORK}

\section{RELATIONSHIP FLEXIBILITY}

Relationship flexibility is defined as the ability to change the relationship under different conditions[21]. There are three processes involved in relationship flexibility: an expectation of a bilateral willingness to adapt, some kind of coordination change, and the ability to cope with changing conditions. First, when firms show flexibility in their behavior towards partners, they indirectly express their good intentions in the relation [24]. Second, when coordinating amendments to agreements or contracts, the frequency, and quality of information exchange determines the degree to which partners understand each other's goals and coordinates their efforts to achieve those goals [25]. Finally, to the extent that a higher level of relationship flexibility can cope with uncertainties in the distribution channel, channel members will increasingly want to sell or buy the focus firm's products or services and engage with other related businesses to enable the distribution channel. To be more loyal to the members or the end customers focus firm and thus ensure that both parties are willing to maintain a long-term relationship [45].

Relationship flexibility is important for many reasons. It has been associated with export channel performance in the context of jobs close to the consumer[7]. It forms a clear expression of good intentions in a relationship[24]. It increases a buyer's confidence in a supplier's willingness and ability to work together [38]. In the network close to a consumer, it is associated with relatively higher levels of relationship satisfaction and a relatively stronger orientation towards maintaining long-term relationships [10].

Today, with the development of technology, the need to be flexibility in their relations with suppliers or producers will also emphasize the importance of relationship flexibility. It has been argued that the increasing pressure of new technologies and the need to reduce costs forced firms to increase the flexibility of their structures [47]. In summary, relationship flexibility is the state of being open to mutual change according to the current conditions of the existing agreement and principles between the company and the customer.

\section{RELATIONSHIP SATISFACTION}

Relationship satisfaction is defined as "a positive, emotional and rational situation arising from the evaluation of the working relationship of the buyer with the supplier" [26]. Geyskens et al. [17] state that relationship satisfaction is a positive, emotional, and rational situation arising from the evaluation of the buyer's working relationship with the supplier. Relationship satisfaction is seen as a general effect developed throughout a relationship, not as a result of a specific process [14]. Relationship satisfaction means "cognitive and affective evaluation based on personal experience in all... parts in the relationship"[39]. Based on the definitions, it can be stated that relationship satisfaction expresses the general situation in which it is mutual and is based on personal experience. 
Relationship satisfaction forms a vital structure in explaining any relationship between two or more participants. It is seen as a positive and emotional situation arising from the evaluation of all aspects of the relationship between one company and another[40]. In the context of work, relationship satisfaction has also been stated to be a positive emotional state resulting from a firm evaluating all aspects of its working relationship with another firm[14].

In general, three main conditioning factors can be put forward for relationship satisfaction, which is accepted as a global concept. First of all, there is effective two-way communication between the participants who have a positive impact. This refers to the exchange of quality information on multiple levels and areas, which takes place regularly and as needed. This approach is supported by all the literature on the use of non-coercive impact strategies in which information exchange is included, with both satisfaction components [40].

\section{LOGISTICS SERVICE QUALITY}

Logistics service is traditionally defined as a service to transport products from one place to another with a single transport [31]. However, today logistics businesses increasingly offer a comprehensive range of services in one place. These services range from sourcing, storage, assembly, transportation to the consumer and return flow of the material. Therefore, the scope of logistics services has improved tremendously and provides more value in supply chain management [15][22]. They stated that the scope of the services provided by the logistics business has expanded due to the possibility of generating a higher income to respond to the demand of consumers. Therefore, it is difficult to define a clear boundary of logistics services today. As logistics services expand and more parties are involved in the process, a guide to the desired quality of logistics services is important [3].

Service quality or providing quality service is considered as an important strategy for success in today's competitive environment [35]. Companies that provide superior services achieve higher-thannormal growth in market share and increased profits (through offering higher market share and higher prices)[14]. At the same time, the quality of services and goods have been accepted as a strategic variable in achieving efficiency as well as efficiency in commercial activities [36].

Also, the satisfaction of the buyers affects the repeat purchases and the recurring income desire of the businesses [18]. Therefore, logistics service quality integrates logistics theory with practical application in businesses related to this study. Logistics service quality personnel communication quality, order confirmation amount, information quality, order process, order accuracy, order conditions, order quality, order inconsistency management, and timeliness are explained by nine parameters [29].

\section{HYPOTESES}

\section{RELATIONSHIP FLEXIBILITY AND RELATIONSHIP SATISFACTION}

Relationship flexibility is seen as an important factor that can affect relationship quality and relationship performance. Other factors can also be important, and other aspects of flexibility can affect relationship performance [45]. Relationship flexibility is limited by the network context in which it is managed. In a marketing channel, the structure is usually related to the flexibility in a relationship and the social norm of mutual expectations, a dimension often referred to as the "relational norm"[10]. When considered in this context, relationship flexibility can be considered as a factor affecting relationship satisfaction.

Relationship satisfaction is also directly linked to job success [32]. As a result, it is the customer that determines the level of success [11]. In the supply chain relationship, the level of buyer satisfaction is the supplier's responsibility. The authors increasingly emphasize the role of soft factors such as trust in communication [23] and achieving high levels of relationship satisfaction [9][32]. Relationship satisfaction has been recognized as a precursor to cooperation, that is, they coordinated the actions of exchange partners who were guided to achieve mutually common goals [33]. Milosevic et al.[30] intensified communication between exchange partners increases trust in buyer-supplier relationships, which contributes to the buyer's perceptions of relationship satisfaction. According to the results of another study[46] examining the relationship between 
relationship flexibility and relationship satisfaction, relationship flexibility positively affects relationship satisfaction. In this context, the H1 hypothesis "Relationship flexibility positively and significantly affects relationship satisfaction" was formed.

\section{RELATIONSHIP FLEXIBILITY AND LOGISTICS SERVICE QUALITY}

Generally, service quality affects customer satisfaction [16]. The expectations of the customers in order to create or improve the logistics service quality, or the customer and the seller may revise the agreements and procedures when necessary to provide a logistics service. In today's world of global competition, local and international businesses have begun to need to transfer their workload to 3PL companies in order to reduce costs and increase quality and customer satisfaction [2]. Chen et al.[13], it was stated that an overlooked concept in the 3PL research was relationship flexibility and it was mentioned how easy flexible arrangements can be made in the relationship.

In order to achieve the logistics service quality, the flow of information should be provided regularly. Relationship flexibility is accepted as an indicator that the flow of information is regular [20]. According to [37], the first two components that determine the quality in logistics are "delivery on time" and "total support of customer needs". In particular, it is expected to be flexible about delivery on time and to meet customer expectations. In a sense, flexibility should be provided in the relationship between the customer and the seller. In the study conducted by Guliman and Gavrila[19], the effect of relationship flexibility on logistics service quality was investigated. According to the analysis result, when the relationship flexibility is high, the perception of logistics service quality also increases. In this context, the $\mathrm{H} 2$ hypothesis "Relationship flexibility positively and significantly affects the logistics service quality." was formed.

\section{LOGISTICS SERVICE QUALITY AND RELATIONSHIP SATISFACTION}

Considering that the quality of logistics service is conceptualized as the movement process of goods from the order point to the destination point[29], it is expected that the quality of this process will contribute to the satisfaction of both parties in the relationship between the customer and the seller. Leverin and Liljander [27] state that there is a positive relationship between service quality and satisfaction in the banking sector. According to the study conducted by Başanbaş[6] in the automotive sector, there is a positive relationship between quality perception and satisfaction. Based on these, it can be argued that there may be evidence that a service provided will affect relationship satisfaction.

Saura et al. [41] analyze the relationships between logistics service quality, satisfaction, and loyalty in the supply chain with a special perspective on the use of information and communication technology (ICT). Their studies confirm the positive effect of logistics service quality and timeliness on satisfaction, which positively affects loyalty. There is a positive relationship between logistics service quality and relationship satisfaction[14]. This relationship shows a direct relationship. Since it affects relationship flexibility logistics service quality (Chen et al., 2015) and relationship satisfaction ][10], it should also be questioned whether logistics service quality has a mediating role in the relationship between relationship flexibility and relationship satisfaction. In the study conducted by $\mathrm{Yu}$ et al.[46], it was determined that logistics service quality has a mediating role in the relationship between relationship flexibility and relationship satisfaction. In this context, the following hypotheses have been developed. In this context, the H3 "Logistics service quality positively and significantly affects relationship satisfaction" and H4 "Logistics service quality has a mediation role in the effect of relationship flexibility on relationship satisfaction" hypotheses were formed. 


\section{METHOD}

\section{RESEARCH MODEL AND DATA ANALYSIS}

The research model presented in Figure 1 was created to be tested as a result of the conceptual review made within the scope of the research. The hypotheses created include the determination of both direct and indirect effects. Therefore, SEM analysis was conducted to test the hypotheses within the scope of the model created. The steps suggested by Baron and Kenny [5] were followed for mediation analysis. According to this model, the direct effect of the independent variable on the dependent variable will be calculated. Then the indirect effect will be calculated. SPSS Process V3.4 Macro was used to calculate the beta values to be used to determine the mediation effect [. For the statistical significance of the mediator variable, the Sobel test was used [8].

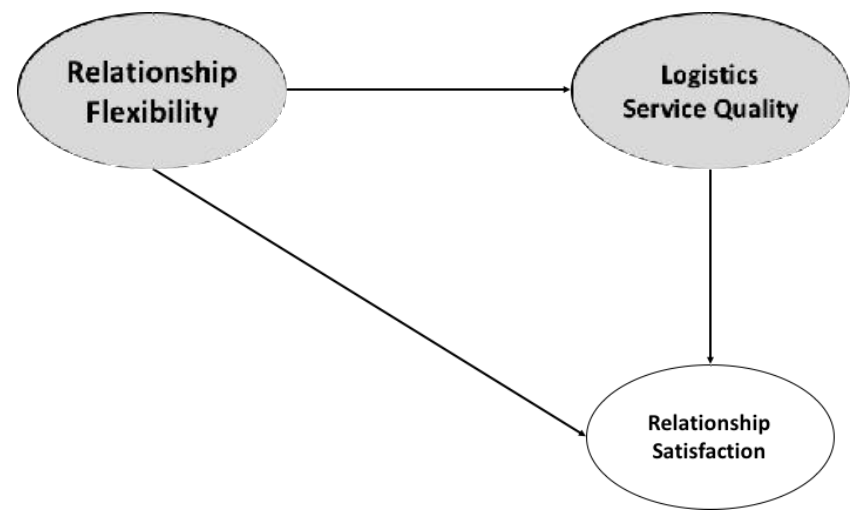

Figure 1. Theoretical Model

\section{POPULATION AND SAMPLE}

A questionnaire form was sent by e-mail to a total of 1627 medium and large-scale business executives registered to the Gaziantep Chamber of Industry. 366 of campanies returned. The return rate of the questionnaires is $22.5 \%$. According to Can [12], when the universe size is 2000 , the sample should be at least 322 from $95 \%$ confidence interval.

\section{DATA COLLECTION TOOLS}

Three scales were used in the study: relationship flexibility, relationship satisfaction, and logistic service quality. The relationship flexibility scale was developed by Heide and Jonh [21] and updated by [42]. The KMO for the relationship flexibility scale was 0.701 , and the Barlett-Sphericity Test $\chi 2$ value was calculated as 65.739 and $(\mathrm{p}<0.05)$. As a result of the analysis, a single factor structure that explains $51.67 \%$ of the total variance with an eigenvalue of 2.067 was obtained. The factor loads of the scale range between 0.547 and 0.807 .

Logistics service quality is the original scale of Parasuraman et al. [35] although it has been adapted and used by many researchers. In this study, the scale is same with the study conducted by Yu et al. [46]. The scale has three sub-dimensions: timeliness, availability, conditions and quality. As a result of the analysis, there are 3 factors with an eigenvalue greater than 1. Eigenvalues are factor-1 3.038, factor-2 1.747 and factor-3 $1.071 .65 .061 \%$ of the total variance is explained. The item "There is a wide variety of products" in factor loads resulting from the rotation process because the loads in two factors are close to each other, the item was removed, and the process was repeated. KMO was calculated as 0.661, BartlettSphericity Test $\chi^{2}$ value was calculated as 226.205 and $(\mathrm{p}<0.05)$. As a result of the analysis, there are 3 factors with an eigenvalue greater than 1. Eigenvalues are factor-1 2.273, factor-2 1.746 and factor-3 1.066. $69.57 \%$ of the total variance is explained. 
The relationship satisfaction scale has been adapted by Webb and Hogan [43] from the study of Anderson and Narus (1984). KMO was calculated 0.787, Barlett Sphericity Test $\chi 2$ value was calculated as 192.515 and $(\mathrm{p}<0.05)$. As a result of the analysis, a single factor structure that explains $70.96 \%$ of the total variance with an eigenvalue of 2.338 was obtained. The factor loads of the scale vary between 0.794 and 0.892 .

Table 1. Model Fit Indices for the Validity of the Scales

\begin{tabular}{|l|l|l|l|l|l|l|l|l|}
\hline Scale & $\chi^{2}$ & $\mathrm{df}$ & RMSEA & RMR & GFI & IFI & CFI & NFI \\
\hline $\begin{array}{l}\text { Relationship } \\
\text { flexibility }\end{array}$ & 1.953 & 2 & 0.000 & 0.019 & 0.990 & 1.000 & 1.000 & 0.971 \\
\hline $\begin{array}{l}\text { Logistics } \\
\text { service quality }\end{array}$ & 18.781 & 17 & 0.032 & 0.054 & 0.956 & 0.992 & 0.991 & 0.921 \\
\hline $\begin{array}{l}\text { Relationship } \\
\text { satisfaction }\end{array}$ & 0.917 & 1 & 0.000 & 0.007 & 0.995 & 1.000 & 1.000 & 0.995 \\
\hline
\end{tabular}

In the evaluation of the results obtained for CFA, the model fit index values suggested by SchermellehEngel, Moosbrugger and Müller[ (2003) were taken as criteria. Model fit indices presented in Table 1 are at acceptable levels.

Table 2. Cronbach Alpha and Composite Reliability Values

\begin{tabular}{|l|l|l|l|}
\hline Scale & Items & Cronbach Alpha & Composite Reliability \\
\hline $\begin{array}{l}\text { Relationship } \\
\text { flexibility }\end{array}$ & 4 & 0,688 & 0,69 \\
\hline $\begin{array}{l}\text { Logistics service } \\
\text { quality }\end{array}$ & 8 & 0,723 & 0,90 \\
\hline $\begin{array}{l}\text { Relationship } \\
\text { satisfaction }\end{array}$ & 4 & 0.863 & 0.86 \\
\hline
\end{tabular}

According to the reliability coefficients of both Cronbach Alpha and Compozit, the scales are above acceptable values (Table 2). In sum, all scales are valid for these participants.

\section{FINDINGS}

\section{STRUCTURAL EQUATION MODEL}

Within the scope of the research, SEM was created to investigate the effect of the relationship flexibility on logistic service quality and the relation satisfaction. The indexes for the model are given in Table-3 below.

Table 3. Model Fit Indices for Structural Equation Model

\begin{tabular}{|l|l|l|l|l|l|l|l|}
\hline Model & $\mathrm{X} 2 / \mathrm{df}$ & RMSEA & RMR & GFI & IFI & CFI & NFI \\
\hline SEM & $\begin{array}{l}7.733 / 3 \\
=2.57\end{array}$ & 0.067 & 0.018 & 0.991 & 0.984 & 0.983 & 0.974 \\
\hline
\end{tabular}

When the model fit indices are examined, it is seen that the created model is in a good fit. Then regression values were examined to determine the level of association.

Table 4. Path Values of Structured Model

\begin{tabular}{|l|l|r|r|r|r|}
\hline Hypoteses & Path & $\beta$ & \multicolumn{1}{|c|}{ S. Error } & \multicolumn{1}{|c|}{ z-score } & Standard $\beta$ \\
\hline H2 & $\begin{array}{l}\text { relationship flexibility } \rightarrow \text { Logistics service } \\
\text { quality }\end{array}$ & 0.200 & 0.045 & $4.499^{*}$ & 0.54 \\
\hline H1 & $\begin{array}{l}\text { relationship flexibility } \rightarrow \text { relationship } \\
\text { satisfaction }\end{array}$ & 0.168 & 0.087 & 1.924 & 0.03 \\
\hline H3 & $\begin{array}{l}\text { Logistics service quality } \rightarrow \text { relationship } \\
\text { satisfaction }\end{array}$ & 1.592 & 0.350 & $4.547^{*}$ & 0.75 \\
\hline
\end{tabular}

According to these results, "H2: Relationship flexibility positively and significantly affects the quality of logistics service" and "H3: Logistics service quality affects relationship satisfaction positively and significantly" hypotheses are accepted, "H1: Relationship flexibility affects relationship satisfaction positively and significantly." hypothesis was rejected. 


\section{MEDIATING ROLE}

Table 5. Regression Results of Logistics Service Quality and Relationship Satisfaction

\begin{tabular}{|c|c|c|c|c|c|c|c|c|}
\hline \multirow[t]{2}{*}{ Variables } & \multicolumn{4}{|c|}{ Logistics service quality } & \multicolumn{4}{|c|}{ Relationship Satisfaction } \\
\hline & $\begin{array}{l}\beta \\
\text { (S.H.) }\end{array}$ & $\mathrm{t}$ & $\mathrm{p}$ & $\begin{array}{l}\text { Standart. } \\
\beta\end{array}$ & $\begin{array}{l}\beta \\
\text { (S.H.) }\end{array}$ & $\mathrm{t}$ & $\mathrm{p}$ & $\begin{array}{l}\text { Standart. } \\
\beta\end{array}$ \\
\hline $\begin{array}{l}\text { Relationship } \\
\text { flexibility }\end{array}$ & $\begin{array}{l}0,302 \\
(0,048)\end{array}$ & 6,289 & $0,000 *$ & 0,319 & $\begin{array}{l}0,431 \\
(0,054)\end{array}$ & 7,922 & $0,000^{*}$ & 0,380 \\
\hline \multirow[t]{3}{*}{$\begin{array}{l}\text { Logistics } \\
\text { service } \\
\text { quality } \\
\end{array}$} & & & & & $\begin{array}{l}0,319 \\
(0,057)\end{array}$ & 5,560 & $0,000^{*}$ & 0,267 \\
\hline & \multicolumn{4}{|c|}{$\begin{array}{l}\mathrm{R} 2=0,102 \\
\mathrm{~F}(1,349)=39,355^{*}\end{array}$} & \multicolumn{4}{|c|}{$\begin{array}{l}\mathrm{R} 2=0,530 \\
\mathrm{~F}(3,352)=67,793^{*}\end{array}$} \\
\hline & $\mathrm{z}=4,182$ & $p=0.00$ & & & & & & \\
\hline
\end{tabular}

It was determined that relationship flexibility and logistics service quality were positive and significant, and also, together with relationship flexibility, the relationship between logistics service quality had a positive and significant effect on relationship satisfaction. Then, the Sobel test was conducted to determine the significance of the mediating effect. Since the test result is $\mathrm{z}=4.182$ (sh 0.023) and $\mathrm{p}=$ 0.000 , it can be said that the mediating effect is statistically significant. As a result, "H4: Logistics service quality has a mediation role in the effect of relationship flexibility on relationship satisfaction." hypothesis is accepted.

\section{DISCUSSION AND COUNCLUSION}

It was concluded that logistics service quality has a mediating role in the effect of relationship flexibility on relationship satisfaction. This result is in line with the study conducted by Yu et al.[46] . Regarding the effect of relationship flexibility on logistic service quality, it was concluded that relationship flexibility had a positive and significant effect. According to Chen et al.[13], relationship flexibility affects the quality of logistics service. In addition, Yu et al. [46] similar results are obtained in the study. This result obtained in the study is consistent with the studies in the literature. When the effect of logistics service quality on relationship satisfaction is examined, it is concluded that logistics service quality affects relationship satisfaction positively and significantly. Some studies [14][46] determined that there is a positive relationship between logistics service quality and relationship satisfaction. It has been determined that the quality of logistics service has a key role in improving relationship flexibility, which is seen as important in many studies [14][40]. In other words, increasing the logistics service quality will directly increase the success of organizations.

Relationship flexibility, which is seen as a two-way expectation of willingness to adapt by coordinating the use of relational resources, affects the quality of logistics service and relationship satisfaction [45]. In this study, it was concluded that the inclusion of logistics service quality in the model and relationship flexibility did not have a direct and significant effect on relationship satisfaction. When the effect values of mediation are examined, it is defined as the full mediator that the effect of the independent variable on the dependent variable is not statistically significant with the inclusion of the mediator variable in the model [5][8]. It is thought that the failure to verify the hypothesis may be due to the inclusion of logistics service quality in the structural equation model. Study findings play an important role in logistics service quality relationship satisfaction. When considered in this context, it can be ensured that the quality of logistics service can be increased by applying flexible principles, taking into account the demands of the customers.

\section{LIMITATIONS}

In the research, scales were used as a data collection tool. The personal thoughts of the participants may have come to the forefront in the information given about the company since the individuals were 
formed in accordance with their own statements. In addition, not all companies in Gaziantep OSB have filled the measurement tool. Therefore, it will create a limitation while generalizing. In the sample of the study, it covers the large and medium-sized companies in Gaziantep OSB. The study is out of scope for small-scale companies. The study is limited to the measurement of logistics flexibility, relationship flexibility, logistics service quality, relationship satisfaction and environmental uncertainty and determining the relationship between them.

\section{REFERENCES}

[1] Abdul-Muhmin, A. G. (2005). Instrumental and interpersonal determinants of relationship satisfaction and commitment in industrial markets. Journal of Business Research, 58(5), 619-628. https://doi.org/10.1016/j.jbusres.2003.08.004

[2] Akben, İ., \& Fidan, O. (2019). Demir çelik sektöründe logistikte dış kaynak kullanımı (3PL): İskenderun bölgesinde bir inceleme [external resources use in logistics in the iron and steel sector (3PL): a review in iskenderun region]. 8. ULUSAL LOJISTIKK VE TEDARİK ZINCIRİ KONGRESI, 431-444.

[3] Alvina, P. (2019). Blockchain Technology Applications in the Business Processes of Logistics Enterprises. Unpublished Master's Thesis, Swedish KTH School of Industrial Engineering and Management.

[4] Anderson, J. C., \& Narus, J. A. (1984). A Model of the Distributor's Perspective of DistributorManufacturer Working Relationships. Journal of Marketing, 48(4), 62-74. https://doi.org/10.1177/002224298404800407

[5] Baron, R. M., \& Kenny, D. A. (1986). The Moderator-Mediator Variable Distinction in Social Psychological Research. Conceptual, Strategic, and Statistical Considerations. Journal of Personality and Social Psychology, 51(6), 1173-1182. https://doi.org/10.1037/0022-3514.51.6.1173

[6] Başanbaş, Ş. (2012). Algılanan kalite, tatmin ve bağl1lık ilişkisi üzerine otomotiv yan sanayiinde bir araştırma[A research in the automotive supplier industry on the relationship of perceived quality, satisfaction and commitment]. Pazarlama ve Pazarlama Araştırmaları Dergisi, 10, 15-39.

[7] Bello, D. C., \& Gilliland, D. I. (1997). The Effect of Output Controls, Process Controls, and Flexibility on Export Channel Performance. Journal of Marketing, 61(1), 22. https://doi.org/10.2307/1252187

[8] Burmaoğlu, S., Polat, M., \& Meydam, C. H. (2013). Örgütsel Davranış Alanında İlişkisel Analiz Yöntemleri ve Türkçe Yazında Aracılık Modeli Kullanımı Üzerine Bir İnceleme [A Study on Relational Analysis Methods and the Use of Mediation Model in Turkish Literature in the Field of Organizational Behavior]. Anadolu Üniversitesi Sosyal Bilimler Dergisi, 13(1), 13-26.

[9] Cadden, T., Marshall, D., Humphreys, P., \& Yang, Y. (2015). Old habits die hard: Exploring the effect of supply chain dependency and culture on performance outcomes and relationship satisfaction. Production Planning and Control, 26(1), 53-77. https://doi.org/10.1080/09537287.2013.848478

[10] Cadeaux, J. (2015). The Effects of Stability, Diversity, and Density on Relationship Flexibility in an International Retail Supply Network: A Proposed Theory and Research Hypotheses. Entrepreneurship in International Marketing Advances in International Marketing, 25, 307-320. https://doi.org/10.1108/S1474-797920140000025014

[11] Cambra-Fierro, J. J., \& Polo-Redondo, Y. (2008). Creating satisfaction in the demand-supply chain: The buyers' perspective. Supply Chain Management, 13(3), 211-224. https://doi.org/10.1108/13598540810871253

[12] Can, A. (2014). SPSS ile Nicel Veri Analizi[Quantitative Data Analysis with SPSS]. Pegem Akademi.

[13] Chen, H., Zemanek, J. E., Mai, E., \& Tian, Y. (2015). Relationship Flexibility in a 3PL Context: Impacts of Network Embeddedness, Guanxi, and Explicit Contract. Journal of Marketing Channels, 22(4), 253-264. https://doi.org/10.1080/1046669X.2015.1113490

[14] Chumpitaz Caceres, R., Paparoidamis, N. G., Caceres, R. C., \& Paparoidamis, N. G. (2007). Service quality, relationship satisfaction, trust, commitment and business-to-business loyalty. European Journal of Marketing, 41(7-8), 836-867. https://doi.org/10.1108/03090560710752429 
[15] Czajkowska, A., \& Stasiak-Betlejewska, R. (2015). Quality management tools applying in the strategy of logistics services quality improvement. Serbian Journal of Management, 10(2), 225-234. https://doi.org/10.5937/sjm10-8095

[16] Dado, J., Taborecka-Petrovicova, J., Cuzovic, S., \& Rajic, T. (2012). An empirical examination of the relationships between service quality, satisfaction and behavioral intentions in higher education setting. Serbian Journal of Management, 7(2), 203-218. https://doi.org/10.5937/sjm7-1245

[17] Geyskens, I., Steenkamp, J. B. E. M., \& Kumar, N. (1999). A meta-analysis of satisfaction in marketing channel relationships. Journal of Marketing Research, 36(2), 223-238. https://doi.org/10.2307/3152095

[18] Gil-Saura, I., \& RuizMolina, M. E. (2011). Logistics service quality and buyer-customer relationships: The moderating role of technology in B2B and B2C contexts. Service Industries Journal, 31(7), 1109-1123. https://doi.org/10.1080/02642060903100380

[19] Guliman, B. M., \& Gavrila, L. (2018). Flexibility and Agility Key Indicators in Supply Chain. Rethinking Social Action Core Values in Practice, 5(April), 196-201. https://doi.org/10.18662/lumproc.47

[20] Hartmann, E., \& De Grahl, A. (2011). The flexibility of logistics service providers and its impact on customer loyalty: An empirical study. Journal of Supply Chain Management, 47(3), 63-85. https://doi.org/10.1111/j.1745-493X.2011.03228.x

[21] Heide, J. B., \& John, G. (1992). Do Norms Matter in Marketing Relationships? Journal of Marketing, 56(2), 32. https://doi.org/10.2307/1252040

[22] Huemer, L. (2012). Unchained from the chain: Supply management from a logistics service provider perspective. Journal of Business Research, 65(2), 258-264. https://doi.org/10.1016/j.jbusres.2011.05.028

[23] Jäckel, M., Rövekamp, C., \& Würfel, A. M. (2006). Beyond digital connectivity: The value of communication and the communication of values. Production Planning and Control, 17(2), 214223. https://doi.org/10.1080/09537280500224192

[24] Johnson, J. L. (1999). Strategic integration in industrial distribution channels: Managing the interfirm relationship as a strategic asset. Journal of the Academy of Marketing Science, 27(1), 418. https://doi.org/10.1177/0092070399271001

[25] Jonsson, P., \& Zineldin, M. (2003). Achieving high satisfaction in supplier-dealer working relationships. Supply Chain Management, 8(3), 224-240. https://doi.org/10.1108/13598540310484627

[26] Lages, L. F., Lancastre, A., \& Lages, C. (2008). The B2B-RELPERF scale and scorecard: Bringing relationship marketing theory into business-to-business practice. Industrial Marketing Management, 37(6), 686-697. https://doi.org/10.1016/j.indmarman.2007.05.008

[27] Leverin, A., \& Liljander, V. (2006). Does relationship marketing improve customer relationship satisfaction and loyalty? International Journal of Bank Marketing, 24(4), 232-251. https://doi.org/10.1108/02652320610671333

[28] Mentzer, J. T., Flint, D. J., \& Hult, G. T. M. (2001). Logistics Service Quality as a SegmentCustomized Process. Journal of Marketing, 65(4), 82-104. https://doi.org/10.1509/jmkg.65.4.82.18390

[29] Mentzer, J. T., Flint, D. J., \& Kent, J. L. (1999). Developing a logistics service quality scale. Journal of Business Logistics, 20(1), 9-32. http://search.proquest.com/openview/d9513979d0431f01637dbda6dd196b45/1?pqorigsite $=$ gscholar \&cbl $=36584$

[30] Milosević, I., Trajković, A., Rajić, T., \& Đorđević, P. (2018). The determinants of cooperation in buyer-supplier relationships: Evidence from certified companies. Industrija, 46(1), 137-153. http://scindeks.ceon.rs/article.aspx?artid=0350-03731801137M

[31] Monczka, R. M., Petersen, K. J., Handfield, R. B., \& Ragatz, G. L. (1998). Success Factors in Strategic Supplier Alliances: The Buying Company Perspective. Decision Sciences, 29(3), 553-577. https://doi.org/10.1111/j.1540-5915.1998.tb01354.x

[32] Morrissey, J. W., \& Pittaway, L. (2006). Buyer-supplier relationships in small firms: The use of social factors to manage relationships. International Small Business Journal, 24(3), 272-298. https://doi.org/10.1177/0266242606063433 
[33] Palmatier, R. W., Dant, R. P., Grewal, D., \& Evans, K. R. (2006). Factors Influencing the Effectiveness of Relationship Marketing: A Meta-Analysis. Journal of Marketing, 70(4), 136-153. https://doi.org/10.1509/jmkg.70.4.136

[34] Parasuraman, A., Zeithaml, V., \& Berry, L. (1985). Conceptual model of service quality and its implications for future research. Journal of Marketing, 49(4), 41-50. https://doi.org/10.1016/S01482963(99)00084-3

[35] Parasuraman, Zeithaml, V. A., \& Berry, L. L. (1988). SERVQUAL: A Multiple-Item Scale for Measuring Consumer Perceptions of Service Quality. Journal of Retailing, 64(1), 12-40. https://doi.org/10.1016/S0148-2963(99)00084-3

[36] Phillips, L. W., Chang, D. R., \& Buzzell, R. D. (1983). Product quality, cost position and business performance: a test of some key hypotheses. Journal of Marketing, 47(2), 26-43.

[37] Rahman, S. U. (2006). Quality management in logistics: An examination of industry practices. Supply Chain Management, 11(3), 233-240. https://doi.org/10.1108/13598540610662130

[38] Roath, A. S., \& Sinkovics, R. R. (2006). Utilizing Relational Governance in Export Relationships: Leveraging Learning and Improving Flexibility and Satisfaction. In Advances in International Marketing (Vol. 16, pp. 157-185). https://doi.org/10.1016/S1474-7979(05)16007-4

[39] Roberts, K., Varki, S., \& Brodie, R. (2003). Measuring the quality of relationships in consumer services: an empirical study. European Journal of Marketing, 37(1/2), 169-196. https://doi.org/10.1108/03090560310454037

[40] Sanzo, M. J., Santos, M. L., Vázquez, R., \& Álvarez, L. I. (2003). The effect of market orientation on buyer-seller relationship satisfaction. Industrial Marketing Management, 32(4), 327-345. https://doi.org/10.1016/S0019-8501(01)00200-0

[41] Saura, I. G., Francés, D. S., Contrí, G. B., \& Blasco, M. F. (2008). Logistics service quality: A new way to loyalty. Industrial Management and Data Systems, 108(5), 650-668. https://doi.org/10.1108/02635570810876778

[42] Wang, E. T. G., \& Wei, H. L. (2007). Interorganizational governance value creation: Coordinating for information visibility and flexibility in supply chains. Decision Sciences, 38(4), 647-674. https://doi.org/10.1111/j.1540-5915.2007.00173.x

[43] Webb, K. L., \& Hogan, J. E. (2002). Hybrid channel conflict: causes and effects on channel performance. Journal of Business \& Industrial Marketing, 17(5), 338-356. https://doi.org/10.1108/08858620210439031

[44] Yıldı, B., \& Çetindaş, A. (2020). Tedarik zinciri entegrasyonunun firma performansı üzerindeki etkisinde tedarik zinciri esnekliği ve tedarik zinciri çevikliğinin aracı rolü [The mediating role of supply chain flexibility and supply chain agility in the impact of supply chain integration . Verimlilik Dergisi, 3, 175-199.

[45] Yu, K., Cadeaux, J., \& Song, H. (2013). Distribution channel network and relational performance: The intervening mechanism of adaptive distribution flexibility. Decision Sciences, 44(5), 915-950. https://doi.org/10.1111/deci.12040

[46] Yu, K., Cadeaux, J., \& Song, H. (2017). Flexibility and quality in logistics and relationships. Industrial Marketing Management, 62, 211-225. https://doi.org/10.1016/j.indmarman.2016.09.004

[47] Zakaria, Z., Kamarolzaman, M., Ahmad, Z., \& Kamaludin, M. A. (2016). Inter Organisational Relationship : Factors Influenc ing Supplier Relationship Management ( SRM ) in Palm Oil Manufacturing. Journal of Applied Environmental and Biological Sciences, 6(1), 77-83.

\section{Article history:}

Received 24 May 2021

Accepted 16 November 2021 